\title{
ANALYSIS
}

\section{Payments for environmental services in watersheds: Insights from a comparative study of three cases in Central America}

\author{
Nicolas Kosoy $^{a}$, Miguel Martinez-Tuna ${ }^{a}$, Roldan Muradian ${ }^{b, *}$, Joan Martinez-Alier ${ }^{a}$ \\ anstitut de Ciència i Tecnologia Ambientals (ICTA), Autonomous University of Barcelona, Building C. 08193, Bellaterra, Barcelona, Spain \\ bevelopment Research Institute (IVO), Tilburg University, P.O. Box 90153, 5000 LE. Tilburg, The Netherlands
}

\section{A R T I C L E I N F O}

\section{Article history:}

Received 17 August 2005

Received in revised form

27 February 2006

Accepted 6 March 2006

Available online 2 May 2006

\section{Keywords:}

Environmental services

Watershed management

Rural development

Property rights

Honduras

Costa Rica

Nicaragua

\begin{abstract}
A B S T R A C T
We have compared three cases of payments for water-related environmental services (PES) in Central America, in terms of socioeconomic background, opportunity costs of forest conservation and stakeholders' perceptions of the conditions of water resources and other issues. We found that, in general, the opportunity costs are larger than the amounts paid, which apparently contradicts the economic foundation of PES schemes and suggests that the role of "intangibles" is important in inducing participation. The results also show that trade-offs between different environmental and social goals are likely to emerge in PES schemes, posing some doubts as to their ability to be multipurpose instruments for environmental improvement and rural development. We also found that PES schemes may work as a conflict-resolution instrument, facilitating downstream-upstream problem solving, though at the same time they might introduce changes in social perceptions of property rights.
\end{abstract}

(c) 2006 Elsevier B.V. All rights reserved.

\section{Introduction}

Even though the theoretical foundations of payments for environmental services (PES) were set several decades ago (Coase, 1960), the practical implementation of these marketbased instruments for managing natural resources has started rather recently. So far, a number of payment schemes at the watershed level have been already implemented, mainly in Latin America, allowing for preliminary lessons to be learned (Landell-Mills and Porras, 2002; Mayrand and Paquin, 2004; Warner et al., 2004; Rosa et al., 2004). These schemes stem from the fact that natural or human-managed ecosystems provide positive environmental externalities, normally not taken into account in individual economic decisions (Pagiola et al., 2002a). The term "environmental services" refers to the provision of these positive externalities. Different types of markets for environmental services have been described in watersheds, from voluntary contractual arrangements to marketable permit systems (Tognetti et al., 2005). The three cases analyzed in the present paper constitute examples of voluntary direct payments from downstream water users to upstream providers of water-related environmental services, through the action of an intermediary agency.

By means of creating market transactions between downstream and upstream economic agents, PES schemes are supposed to induce upstream stakeholders to take downstream effects into account when making decisions about their own land use. This is expected to lead to larger socioeconomic

\footnotetext{
* Corresponding author. Tel.: +31 1346622 64; fax: +31 134663015

E-mail address: roldan@uvt.nl (R. Muradian).
} 
efficiency. Moreover, direct payments are expected to be more cost-effective in meeting environmental and development goals, as compared to indirect means of financing a better stewardship of natural resources (Ferraro and Kiss, 2002). PES schemes are derived from the Coase's theorem. Namely, in a free market with clearly established property rights and no transaction costs, the gains in efficiency due to the internalization of environmental externalities are independent from the direction of the payment, and also from the initial endowment of property rights. Hence, the adoption of the polluterpays principle is not a condition for achieving a Pareto better situation when applying these kinds of instruments. In fact, most water-related PES do not embrace the polluter-pays principle, since upstream landholders are often compensated for avoiding/reducing negative environmental externalities. However, payment schemes for environmental services should fulfill the following two conditions in order to be efficient: i) the compensation of upstream landholders should be at least equal to the opportunity cost of the promoted land use; and ii) the amount of the payment should be lower than the economic value of the environmental externality (for example, the abatement cost of improving water quality).

Direct payments for environmental services have been proposed as promising tools, alternative to command-andcontrol instruments for forest protection (Nathan and Kelkar, 2001), biodiversity conservation (Pagiola et al., 2004) and watershed management. Typically, command-and-control institutions and policies may be effective in controlling pollution from well-defined point sources, such as factories or sewage treatment plants. However, they are less effective in regulating non-point sources of pollution, such as those occurring when downstream water pollution (or scarcity) is the result of the combination of individual actions carried out by geographically disperse and heterogeneous upstream economic agents (Lubell et al., 2002).

In watersheds, direct use rights on forests often belong to upstream landholders. Nonetheless, forests provide a variety of environmental services to diverse stakeholders, at different geographical scales, leading to rivalry in the consumption of forest goods and services. Thus, as in the case of common property resources (Gibson et al., 2000; Ostrom et al., 2002), the resolution of conflicts between different beneficiaries of environmental goods and services from forests typically involves collectively beneficial but individually costly actions. Economic incentives (for the adoption of costly actions) are supposed to be particularly effective in such circumstances (Seabright, 1993). Besides, the institutional arrangement of PES schemes may contribute to reducing transaction and monitoring costs, which are normally assumed to be critical features for solving collective action problems (Taylor and Singleton, 1993).

In tropical watersheds, vulnerable groups tend to be located in upstream areas, where land is usually less productive and more prone to suffer erosion. Nevertheless, these rural communities are often providers of environmental services benefiting other groups with a better socioeconomic situation (often located in downstream urban areas). Hence, PES schemes are also expected to contribute to wealth redistribution and poverty alleviation (Pagiola et al., 2002b; Pagiola, 2005). PES may work as multipurpose (win-win) instruments, improving the conditions of different types of natural re- sources at the same time (e.g. forests and water), raising awareness about the economic worth of ecosystems, and contributing to economic development (Landell-Mills, 2002).

The aim of this article is to compare three cases of payments for environmental services in watersheds, in order to draw lessons about the design, functioning, and local impacts of PES schemes. The following section briefly describes the methodology used. Section 3 summarizes main results. Section 4 discusses the results and develops some insights for PES design.

\section{Methodology}

The fieldwork was carried out in Jesus de Otoro (Honduras), San Pedro del Norte (Nicaragua) and Heredia (Costa Rica) from July to December 2004. These case studies were compared in terms of perception of different stakeholders, institutional context, opportunity costs of upstream land use, and local economic implications of the payment schemes. Stakeholders were classified into four main categories: users, providers, potential providers and intermediaries. Users are the beneficiaries of the environmental services rendered by providers. In our case studies, users are downstream water consumers in urban areas, who pay an additional fee in their water bills, which is allocated to the PES scheme. Providers are upstream agents participating in the PES scheme by means of a contractual relation (with the intermediary) regulating land use. Potential providers are those upstream landholders that are not currently part of the scheme, but may become part of it in the future. Intermediaries are the agents mediating transfer of resources between users and providers. In our cases, the intermediaries are grassroots non-profit organizations (Jesus de Otoro and San Pedro del Norte) and a local public enterprise (Heredia).

We used a combination of quantitative and qualitative research techniques. Structured questionnaires were administered to users, semi-structured questionnaires to providers and potential providers, and in-depth interviews were conducted with key informants and representatives from intermediary organizations. We also collected secondary information on the legal, institutional and socioeconomic contexts. The questionnaires differed depending on the target group. However, all included three main sections: background information, economic aspects and perceptions of the PES scheme, the condition of water resources and other waterrelated issues. Altogether, we conducted 18 interviews and 117 questionnaires in Honduras, seven interviews and 111 questionnaires in Costa Rica, and nine interviews and 65 questionnaires in Nicaragua.

The opportunity costs were estimated by means of calculating three proxy variables: a) net profits from on-farm activities that would be foregone; b) providers' willingness to accept as a "fair price" for PES; and c) the expected rent that would be obtained if the land were rented out. In theory, these three variables should converge, particularly if farmers depend on their land for ensuring their livelihoods. For the present article, net on-farm profit is defined as total production multiplied by the average price of products, minus the cost of inputs (agrochemicals, water, energy, etc.) and the cost of labor, including imputed (own) labor, in a year. The "degree of compensation" is 
calculated deducting the values obtained by means of the above-mentioned proxy variables from the potential or actual amount paid by the PES scheme. A negative value for the "degree of compensation" means that the PES scheme does not (or would not) compensate the opportunity cost.

In San Pedro del Norte, we assume that the three proxy variables applied to providers reveal information that may be used for estimating opportunity costs of forest conservation. Equally, we assume that "on-farm profits" and the "willingness to rent" of potential providers are also proxies for the opportunity costs of forest conservation in this case. The PES scheme in Jesus de Otoro may compensate upstream landholders not only for conserving the forest (as the other two schemes do), but also for adopting better environmental practices. Therefore, in this case, there are two types of opportunity costs: one related to forest conservation, and another arising from the adoption of better environmental practices. The providers we have interviewed in this location are actually being compensated for adopting better practices. The most appropriate way to estimate the opportunity cost of such practices would be to compare the economic performance of landholders before and after the practices were adopted. However, our methodology did not allow for this. As an alternative, we assume that perceptions of a "fair price" by providers might shed information about the opportunity cost of adopting better practices. In addition, in order to estimate the opportunity cost of maintaining forest cover in this case, "onfarm profits" and the "willingness to rent" among potential providers are used as proxies.

In Heredia, urbanization is the most likely alternative land use to forest cover, and the livelihood of providers does not depend on agriculture or cattle raising. Accordingly, we consider that "on-farm profits" is not a good proxy for the opportunity cost of forest conservation. Therefore, we assume that only "willingness to rent" and "fair price" shed meaningful information about opportunity costs in this case. Potential providers in Heredia were not willing to take part in the research, clearly being opposed to the PES scheme. For that reason, they are not included in the results.

\section{Results}

\subsection{Overall description of the case studies}

\subsubsection{Jesus de Otoro, Honduras}

Jesus de Otoro is located in the Department of Itibucá, in the Midwest region of Honduras. It has approximately 5200 inhabitants. The water consumed in this town comes from the watershed of the Cumes River. The area of the watershed is 3180 ha, of which $70 \%$ is covered by forest. Part of the watershed is within the Natural Reserve Montecillos (protected area). The highest elevation of this watershed is 2200 m.a.s.l. Coffee plantations are very common in the upstream area and the main economic activity in the region is agriculture. The local Council for Administration of Water and Sewage Disposal (JAPOE), a grassroots organization, is in charge of managing water provision and sanitation in the town. The creation of JAPOE was a response to serious water problems in the beginning of 1990s. This organization took over the management of water and sanitation services from the municipality. The authorities of JAPOE are elected in general assemblies in ten different sectors of the town, thus it constitutes a decentralized and participatory institution for water and sanitation management. In 1996, an expansion of upstream cultivated areas, mainly coffee, increased the pollution levels in the surface waters, also used as drinking water. This led to severe conflicts between downstream water consumers and upstream landholders. In 2001, the Program for Sustainable Agriculture in Hillsides of Central America (PASOLAC), financed by the Swiss international cooperation, technically supported JAPOE to create a payment scheme for environmental services, and provided the seed capital. At the time the fieldwork was conducted, the scheme offered payments to only four providers and covered about 22 ha. Later, the coverage was expanded to 18 providers and 74 ha. We interviewed three of the four providers. The scheme is meant to promote both the adoption of better environmental practices and the conservation of forests, and is expected to cover up to

Table 1 - Amounts paid to providers (US \$/ha/year)

\begin{tabular}{|c|c|c|c|c|}
\hline \multicolumn{5}{|l|}{ Jesus de Otoro } \\
\hline Forest conservation & $\begin{array}{c}\text { Primary forest } \\
5.5\end{array}$ & & $\begin{array}{c}\text { Secondary forest } \\
4.1\end{array}$ & $\begin{array}{c}\text { Young forest } \\
2.8\end{array}$ \\
\hline Environmental practices & Two practices adopted & & Three practices & Four practices \\
\hline Short cycle crop & 5.5 & & 8.3 & 11 \\
\hline Permanent crop & 8.3 & & 11 & 13.8 \\
\hline Agroforestry & 11 & & 13.8 & 16.6 \\
\hline \multicolumn{5}{|l|}{ Heredia } \\
\hline & Forest conservation & Reforestation, first year & Reforestation, second year & $\begin{array}{c}\text { Reforestation, third to fifth year } \\
67\end{array}$ \\
\hline & 51 & 124 & 100 & 67 \\
\hline \multicolumn{5}{|l|}{ San Pedro del Norte } \\
\hline & Forest conservation & & & \\
\hline & 26.6 & & & \\
\hline
\end{tabular}


200 ha in the future. The amount of the payment depends on the number of "best practices" adopted and on the type of forest protected. The payment amounts are summarized in Table 1.

The land uses promoted are:

- no burning before, during or after planting

- construction of vegetal fences, irrigation ditches and terraces

- establishment of agroforestry systems

- production of organic fertilizers

- recycling of coffee pulp and management of wastes from coffee processing

- implementation of organic agriculture

- forest protection and reforestation.

JAPOE charges water fees to 1269 households. Water users pay an additional fee in their water bill for the PES scheme, which in 2004 was US\$0.06 (1 Lempira) per household per month. The scheme primarily aims to improve water quality. Water availability is not a significant problem in the region.

The creation of the scheme was supported by three technical studies, including an economic valuation. Regardless of the quality of these studies and the reliability of their results, the use of the technical assessments in the design of the scheme was not clear-cut. For example, the actual PES fee was only $3.6 \%$ of the water users' estimated willingness to pay. The final amount of the fee was decided through voting of representatives from the different water sectors in town. The overall cost of design and initial setup of the scheme was about US $\$ 30,000$.

\subsubsection{Heredia, Costa Rica}

Heredia is part of the large urban conglomeration of the Central Valley of Costa Rica. Water for this city comes from the Virilla River watershed. The area of the watershed providing water to Heredia is approximately $11,340 \mathrm{ha}$, and its highest elevation is 2250 m.a.s.l. This PES scheme was designed and managed by ESPH S.A, a public local enterprise for water provision and sanitation. Users are 48,667 households. Part of the Braulio Carrillo National Park is located in this watershed. About $34 \%$ of the Virilla watershed is covered by forest. In 2002, the PES scheme was created in order to avoid deterioration of the upstream area of the watershed, where water sources are located. The scheme prioritized 1062 ha, of which 415 ha are currently part of it. The main goal of the scheme is to prevent deterioration of water quality, since the city currently does not seem to face water scarcity. At the time the fieldwork was conducted, there were ten providers, and all were interviewed. The scheme has identified 29 landholders as potential providers. However, none were willing to participate in this study.

The area where the PES is implemented has also become a high-status residence (or leisure) place for well-paid professionals, who normally work in downstream urban areas, or for foreigners. All of the providers interviewed, except one, held a university degree. Users paid $0.008 \mathrm{US} \$ / \mathrm{m}^{3}$ to the PES scheme, which was about $6 \%$ of the standard water fee for households.

\begin{tabular}{|c|c|c|c|c|c|c|c|}
\hline Provider & $\begin{array}{l}\text { Gross income (on-farm } \\
\text { and off-farm) }\end{array}$ & $\begin{array}{l}\text { PES (in a year) to } \\
\text { gross income }\end{array}$ & $\begin{array}{l}\text { PES/ } \\
\text { area }\end{array}$ & $\begin{array}{l}\text { Net on-farm } \\
\text { profits }\end{array}$ & $\begin{array}{l}\text { "Fair } \\
\text { PES" }\end{array}$ & $\begin{array}{l}\text { Willingness } \\
\text { to rent }\end{array}$ & $\begin{array}{c}\text { Main benefit from } \\
\text { forest }\end{array}$ \\
\hline & US\$/year & $\%$ & $\begin{array}{l}\text { US\$/ha/ } \\
\text { year }\end{array}$ & US\$/ha/year & $\begin{array}{l}\text { US\$/ha/ } \\
\text { year }\end{array}$ & US\$/ha/year & \\
\hline \multicolumn{8}{|c|}{ Jesus de Otoro } \\
\hline 1 & 7625 & 0.4 & 15.9 & & 15.6 & & Wood \\
\hline 2 & 5374 & 1.2 & 11.9 & & 55.6 & & Soil protection \\
\hline 3 & 12,059 & 0.6 & 9.5 & & 19.4 & & Climate regulation \\
\hline Average & 8353 & & 12.4 & & 30.2 & & \\
\hline \multicolumn{8}{|c|}{ San Pedro del Norte } \\
\hline 1 & 4562 & 0.03 & 26.4 & 106 & 89 & 133 & Wood \\
\hline 2 & 3005 & 0.02 & 18.7 & 423 & 266 & 531 & Water \\
\hline 3 & 360 & 0.15 & 26.6 & -39 & 133 & $\mathrm{n} / \mathrm{a}$ & Wood \\
\hline 4 & 863 & 0.08 & 26.6 & -65 & 89 & 354 & Climate regulation \\
\hline 5 & 1329 & 0.03 & 33.1 & 206 & 156 & 319 & Water \\
\hline Average & 2024 & & 26.3 & 126 & 147 & 334 & \\
\hline \multicolumn{8}{|l|}{ Heredia } \\
\hline 1 & 60,000 & 0.7 & 43.0 & & 227 & 200 & Scenery \\
\hline 2 & 90,377 & 0.5 & 21.4 & & 50 & 400 & Climate regulation \\
\hline 3 & 13,800 & 1.6 & 55.7 & & 600 & 1500 & Water \\
\hline 4 & 171,573 & 1.2 & 55.6 & & 100 & 650 & Biodiversity \\
\hline 5 & 19,091 & 9.5 & 51.9 & & 114 & 455 & Scenery \\
\hline 6 & 13,398 & 6.6 & 52.1 & & 80 & $\mathrm{n} / \mathrm{a}$ & Leisure \\
\hline 7 & 33,679 & 1.3 & 30.3 & & 30 & 120 & Water \\
\hline 8 & 4522 & 6.9 & 52.3 & & 68 & 105 & Scenery \\
\hline 9 & 132,000 & 0.1 & 49.0 & & 100 & 300 & Scenery \\
\hline 10 & 52,110 & 21.8 & 42.2 & & $\mathrm{n} / \mathrm{a}$ & 200 & Scenery \\
\hline Average & 59,055 & & 45.4 & & 152 & 466 & \\
\hline
\end{tabular}




\section{Table 3 - Potential providers}

\begin{tabular}{|c|c|c|c|}
\hline $\begin{array}{l}\text { Potential } \\
\text { provider }\end{array}$ & $\begin{array}{l}\text { Gross income (on- } \\
\text { farm and off-farm) }\end{array}$ & $\begin{array}{l}\text { Net on- } \\
\text { farm } \\
\text { profits }\end{array}$ & $\begin{array}{l}\text { Willingness } \\
\text { to rent }\end{array}$ \\
\hline & US\$/year & $\begin{array}{c}\text { US\$/ha/ } \\
\text { year }\end{array}$ & $\begin{array}{c}\text { US\$/ha/ } \\
\text { year }\end{array}$ \\
\hline \multicolumn{4}{|c|}{ Jesus de Otoro } \\
\hline 1 & 1353 & 262 & 79.4 \\
\hline 2 & 3157 & 603 & 23.8 \\
\hline 3 & 2957 & 1079 & 79.4 \\
\hline 4 & 2267 & -78 & 12.7 \\
\hline 5 & 1165 & 231 & 44.1 \\
\hline 6 & 836 & 384 & 14.7 \\
\hline 7 & 1252 & -189 & 111.1 \\
\hline 8 & 2822 & 192 & 27.6 \\
\hline 9 & 3588 & 287 & 33.9 \\
\hline Average & 2155 & 308 & 47.4 \\
\hline \multicolumn{4}{|l|}{ San Pedro } \\
\hline 1 & 1223 & 76 & 53 \\
\hline 2 & 2321 & 297 & 62 \\
\hline 3 & 1485 & -9 & 62 \\
\hline 4 & 301 & 206 & 266 \\
\hline Average & 1333 & 142.5 & 111 \\
\hline
\end{tabular}

ESPH has also established an agreement with a beverage company consuming local water resources (Florida Ice and Farm Co) for allocating additional resources to the PES scheme. Table 1 summarizes the amounts paid to providers for forest conservation and reforestation. The scheme promotes the following land uses and practices:

- prevention and control of forest fires

- no hunting or illegal extraction of forest products

- no extraction of wood products

- forest conservation: no forest conversion to agriculture or cattle ranching

- reforestation (optional).

In 2003, the scheme also invested a considerable part of the fund for land acquisition in the upstream area. As in Jesus de Otoro, the relationship between the outputs of the technical studies supporting the initial design of the scheme and its final functioning and structure was not straightforward. For example, the fee charged to users was decided on political grounds, and is considerably lower than their estimated willingness to pay. The cost of the initial setup of the scheme was about US $\$ 32,000$.

\subsubsection{San Pedro del Norte, Nicaragua}

The "Paso de Los Caballos" watershed is located in the western region of Nicaragua. It has a tropical climate characterized by a strong dry season, and its area is about 741 ha, $21 \%$ of which is covered by forests. The main economic activities in the region are agriculture and cattle ranching. This watershed supplies water to 125 households in San Pedro del Norte. Dwellers in this locality face considerable water problems, both in terms of quality and availability. Locally, these problems are often attributed to the highly degraded forests. This PES scheme shares many features with the scheme in Jesus de Otoro. The Water Committee currently in charge of the PES was created to take over water provision and sanitation, as a local response to the inefficient service previously provided by a public enterprise. As in Jesus de Otoro, PASOLAC introduced the idea of the PES scheme, and provided a seed fund for background technical studies and setting up the system in 2003. Prior to the establishment of the PES, PASOLAC sponsored the visit of a delegation from the local Water Committee and the Municipality to Jesus de Otoro, in order to learn from the experience gained in this case. At the time the fieldwork was conducted, five upstream landowners and 39 ha were part of the PES scheme.

One hundred and twenty five households contribute with US\$ $0.31 /$ month to the PES scheme. As in Jesus de Otoro, the fee was decided through a participatory process in the Water Committee, and differs considerably from the estimates of willingness to pay made by the technical reports. Each provider receives approximately US\$26/ha/year. This amount was set through negotiations between the Water Committee and each of the providers. The cost of the initial setup was approximately US $\$ 10,000$, some of which goes to current payments. The scheme promotes the following land uses:

- conserve and manage the forested area

- prevention and control of forest fires

- restricted timber extraction

- implementation of a management plan

- livestock raising is not allowed

- subsistence crop farming is allowed only in one hectare per provider, without the use of pesticides and agro-chemicals.

\subsection{Quantitative analysis}

\subsubsection{Providers and potential providers}

The socioeconomic characteristics of the three places noticeably differ. Providers and potential providers in Jesus de Otoro

Table 4 - Degree of compensation

Method 2

farm profits) (fair price) (willingness to rent)

Jesus de Otoro

Providers $^{\mathrm{a}}$

Potential

$-302$

$-19$

providers $^{\mathrm{b}}$

San Pedro

Providers

Potential

$-100$

$-116$

$-120$

$-308$

providers

Heredia

Providers

$-107$

$-421$

(PES-Opportunity cost). Average. US\$/ha/year.

a Opportunity cost of better environmental practices.

b Opportunity cost of forest conservation (assuming a PES equal to 5.52 US\$/ha/year). 
Table 5-Socioeconomic background and perceptions of users

\begin{tabular}{lccc} 
& $\begin{array}{c}\text { Jesus de } \\
\text { Otoro }\end{array}$ & $\begin{array}{c}\text { San } \\
\text { Pedro }\end{array}$ & Heredia \\
\hline N of the survey & 100 & 56 & 100 \\
Average income, US\$/month & 245 & 66 & 952 \\
Payment to the PES scheme, US\$/ & 0.06 & 0.31 & 0.008 \\
household/month & & &
\end{tabular}

(in Heredia US\$/m3)

Education (\%)

No formal education

Incomplete primary school

Complete primary school

Incomplete secondary school

Complete secondary school

University education (complete or

incomplete)

Water consumption (\%)

Drink water directly form the faucet

Boil water

Buy potable water

Filter water

Other purification methods

$\begin{array}{rrr}6 & 16 & 0 \\ 29 & 45 & 20 \\ 17 & 10 & 5 \\ 25 & 9 & 24 \\ 21 & 18 & 9 \\ 2 & 2 & 41\end{array}$

Perception of the relationship between forest cover and water (\%)

$\begin{array}{llll}\text { More forest leads to better water } & 85 & 91 & 97\end{array}$

quality

More forest leads to more

$93-100-(-208$

water quantity

Lack of relationship between forest

cover and water quality

Lack of relationship between

forest cover and water quantity

Negative relationship between

forest cover and water quality

Negative relationship between

forest cover and water quantity

Main benefits from forests (\%)

Water provision

Climate regulation

Watershed protection

Wood and firewood

Non-timber forest products

Beauty and biodiversity

Don't know

Perception on PES and water service (\%)

Awareness of the scheme

Agree with the amount of the

7

7

3

payment

Water availability has improved

during the past two years

Water quality has improved during

the past two years

Water availability has not changed

during the past two years

Water quality has not changed

during the past two years

Water availability has worsened

during the past two years

Water quality has worsened during

the past two years

Overall quality of water service

is good
Table 5 (continued)

\begin{tabular}{lccc} 
& $\begin{array}{c}\text { Jesus de } \\
\text { Otoro }\end{array}$ & $\begin{array}{c}\text { San } \\
\text { Pedro }\end{array}$ & Heredia \\
\hline $\begin{array}{l}\text { Overall quality of water service } \\
\text { is regular }\end{array}$ & 16 & 30 & 10 \\
$\begin{array}{l}\text { Overall quality of water service } \\
\text { is bad }\end{array}$ & 5 & 59 & 0 \\
$\begin{array}{l}\text { Receive permanent water supply } \\
\text { throughout the year }\end{array}$ & 98 & 50 & 97 \\
\hline
\end{tabular}

and San Pedro del Norte are relatively poor peasants, who to a large extent rely on their land for their livelihoods. Their subsistence farming systems are characterized by low, or even negative, on-farm profits. In Heredia, providers are wealthy professionals who do not depend on their land for their incomes (see Tables 2 and 3). Miranda et al. (2003) also found that the main beneficiaries of PES schemes in the Virilla watershed are wealthy landholders, as in other cases in Costa Rica (Zbinden and Lee, 2005).

The amount received from the PES scheme constitutes less than $2 \%$ of gross annual income for most providers, in the three cases (see Table 2). Most providers do not think that the amount they receive as payment for environmental services is "fair". Both providers and potential providers in San Pedro del Norte should state similar values for "net on-farm profits", "fair PES" and "willingness to rent", since the expected rent from land should be at least the actual benefits from farming activities. Equally, providers in Heredia should report similar "fair PES" and "willingness to rent". Nonetheless, the abovementioned values noticeably differ. These results show that the estimation of the opportunity costs may differ considerably, depending on the method used, and the assumptions adopted.

Table 4 shows averages of actual or potential "degree of compensation" by the PES schemes, according to different methods for estimating opportunity costs in the three case studies. "Potential compensation" applies to potential providers. In general, we found that opportunity costs were larger than the actual or potential payment, regardless of the method used.

\subsubsection{Users}

Notwithstanding differences in their socioeconomic background (see Table 5), users in the three cases share a number of common features. The results of the information gathered from users may be summarized as follows:

- The impact of the PES scheme on the users' income is low.

- Most users consume water directly from the tap, which means that they are vulnerable to water quality problems.

- The majority of users share the belief that a larger forest cover will lead to both better water quality and greater water availability.

- Most users perceive that water provision is the most important benefit from forests.

- Most users are not aware of the existence of the PES scheme. When the scheme was explained, the majority of users in Heredia and Jesus de Otoro agreed with the amount of the payment. However, only $29 \%$ of the surveyed users in San Pedro del Norte agreed with such amount. 
- A large majority of users in Jesus de Otoro and Heredia think that the water service provided by the intermediary is good and reliable throughout the year, while most users in San Pedro del Norte consider that the overall quality of the service is bad.

- The majority of users in both Jesus de Otoro and San Pedro del Norte perceive that water quality and availability have improved during the past two years, while in Heredia most users consider that the quality of the service has not changed during the past two years (it has remained good).

\section{Discussion and insights for PES design}

Our results suggest that the selection of the method for estimating opportunity costs is an important step when planning background studies supporting PES design. Since outcomes may differ considerably depending on the method selected, sensitivity analyses are strongly recommended.

We were unfortunately unable to estimate the opportunity costs for the adoption of better environmental practices in Jesus de Otoro by means of calculating changes in productivity induced by the adoption of better practices, which would probably shed interesting insights on this issue. We expect that it is easier to fully compensate for the opportunity cost of adopting better practices than for protecting the forest or reforesting, as is suggested by a higher degree of compensation for adopting better practices as estimated by Method 2 in Jesus de Otoro. A cost-effectiveness analysis of alternative land uses that might be promoted by the payments is an appealing topic for further research, and a necessary input to the design of effective PES schemes.

We have found that, in general, the degree of compensation is negative, irrespective of the estimation method. These empirical findings, suggesting that the amounts of the payments are below the opportunity costs, apparently challenge the economic foundation of PES schemes, since upstream landholders should demand as compensation at least the value of the foregone economic benefits. There are a number of possible interpretations for this outcome. First, if one adopts the proposition that providers are rational economic actors, we should assume that as long as providers voluntarily participate in the scheme, their opportunity costs are indeed compensated; otherwise they would simply decline to do so. If this is the case, negative "degrees of compensation" are a methodological artifact, which might be generated by a variety of causes. For example, it is possible that the opportunity cost of forest protection is overestimated by "on-farm profits". This is likely if the current area covered by forest is not very suitable for agricultural production or cattle raising (for example, because it is located in steep slopes, or in poor soils), and therefore has a low value for landholders. Another factor that may explain this result is that landholders obtain economic benefits from forests' environmental goods and services, such as provision of firewood, non-timber products, shade or scenery. These direct or indirect economic benefits provided by forest to upstream landholders were not estimated in this study. However, providers mentioned as main forests benefits, goods and services that are related to farm production, such as fire- wood, soil protection and climate regulation (see Table 2), while water provision was the main forest benefit identified by downstream users (see Table 5). A third explanation may be that farmers have systematically overstated their profits, willingness to rent their land and perceptions of a "fair" price for PES, as a bargain strategy for obtaining higher payments. Furthermore, in-kind payments, such as technical training, may also play an important role in motivating providers to adopt the PES scheme. In fact, all providers in Jesus de Otoro stated that these kinds of supporting activities constituted significant benefits of the PES scheme.

Nonetheless, if providers are assumed to be agents with "bounded rationality", other types of explanations may be also explored. For example, an alternative interpretation might be that providers perceive the payment as a "support" (some providers explicitly used the word "apoyo"), namely a token incentive - though not significant in terms of the household economy - to implement socially desirable activities. According to the results of our interviews, the perception that the payment is a "support" for activities that they will carry out even if the payments were absent is common among providers. Small payments are probably unable to induce major land use transformations favoring environmental protection. However, they may play a significant role in reinforcing (socially acknowledging) good environmental stewardship. Local social and cultural features, such as religious or social habits, environmental awareness and education programs, may induce forest conservation, even though it may be economically inefficient from the individual point of view. For example, in Heredia there is a noteworthy difference in the perception of providers and potential providers towards the PES scheme. Whilst providers will very likely keep the remaining forest cover on their land, independently of the payment, potential providers are strongly reluctant to participate in the scheme. We think that this has more to do with the attitude of stakeholders towards the environment than with compensation of opportunity costs. Paradoxically, landholders already committed to forest conservation are the ones who participate as providers, while those upstream landholders prone to deforestation and urbanization will possibly permanently decline to be part of it. This brings about some doubts about the costeffectiveness of the payments vis-à-vis alternative tools for downstream-upstream concerted action. This is a critical point to take into account in the initial design of PES schemes.

On the other hand, providers are somehow pressed by other social groups to adopt practices benefiting the commons. Property rights might in theory be clearly defined, but in fact environmental conflicts are about who enjoys and who pays for the environment. For instance, the latent threat to incorporate upstream lands into protected areas seems to have played a role in convincing providers in Jesus de Otoro and Heredia to be part of the scheme. Their lands are near protected areas that were established in part for ensuring the conservation of headwaters.

\footnotetext{
${ }^{1}$ The estimation of opportunity costs among landholders in developing countries is a daunting task, since it depends on a large number of assumptions; landholders usually do not register their transactions, and strategic answers are unavoidable.
} 
The extent to which the above-mentioned and other kind of "intangibles" may influence upstream land husbandry is an interesting and promising area for research (Bergsma, 2000). Even though our results are not yet conclusive (due to our methodological constraints ${ }^{1}$ ), we think our findings have a heuristic value. They may shed new light on working hypotheses to be tested in future research, particularly in relation to the role of intangibles such as social relations, perceptions, conflicts and negotiations in inducing/preventing participation among providers and users. Since the willingness to participate in these markets is not only a matter of compensating opportunity costs or willingness to pay, "intangibles" may play a very critical role in the design and performance of PES schemes. Social aspects may either reduce the cost of implementing PES (e.g. facilitating participation in spite of low payments), or bring about insurmountable barriers to the creation of such markets.

The fact that the payment has a small impact on the income of both providers and users has a number of implications. First, since the additional cost is low, users are keen to pay it and to agree with the scheme, as in Heredia and Jesus de Otoro. The lower acceptance among users in San Pedro may be explained in part by a bad reputation of the local water service, a larger share of the PES fee to users' average income (see Table 4) and the recent implementation of the scheme. Secondly, since the additional fee is very low, it does not constitute an economic incentive for reducing water demand. This may impose some limitations on the PES as an instrument to increase water availability. Thirdly, a small impact on the income of providers makes the PES scheme both more vulnerable to external factors and probably an ineffective tool for poverty alleviation or wealth redistribution in cases such as San Pedro del Norte and Jesus de Otoro. This is a

\begin{tabular}{|c|c|}
\hline $\begin{array}{l}\text { Conventional } \\
\text { wisdom }\end{array}$ & Scientific evidence \\
\hline $\begin{array}{l}\text { Forests increase } \\
\text { runoff }\end{array}$ & $\begin{array}{l}\text { With the exception of cloud forests, runoff } \\
\text { in forested areas is lower than in those with } \\
\text { shorter vegetation. }\end{array}$ \\
\hline $\begin{array}{l}\text { Forests increase dry } \\
\text { season flows }\end{array}$ & $\begin{array}{l}\text { This effect is site-specific. Afforestation } \\
\text { may result in either increased or reduced } \\
\text { dry season flows. }\end{array}$ \\
\hline $\begin{array}{l}\text { Forests reduce peak } \\
\text { flows }\end{array}$ & $\begin{array}{l}\text { Once a new vegetation cover is well- } \\
\text { established, peak flows no longer differ } \\
\text { from forested conditions. The effect is of } \\
\text { decreasing importance as the size and the } \\
\text { number of tributaries in the basin increase. } \\
\text { Under certain conditions, large storm flows } \\
\text { may also emerge from forested areas. }\end{array}$ \\
\hline $\begin{array}{l}\text { Forests encourage } \\
\text { more rainfall }\end{array}$ & $\begin{array}{l}\text { This only holds in the case of large-scale } \\
\text { deforestation. Local precipitation is not } \\
\text { significantly affected by forest cover (with } \\
\text { the exception of cloud forests) }\end{array}$ \\
\hline $\begin{array}{l}\text { Forests increase } \\
\text { groundwater } \\
\text { recharge }\end{array}$ & $\begin{array}{l}\text { Groundwater recharge is affected in a } \\
\text { similar way to seasonal flows }\end{array}$ \\
\hline
\end{tabular}

Summary of the reviews made by Calder (2004), Ayward (2005) and Bruijnzeel et al. (2005). critical issue since these instruments, although not having poverty reduction as their primary concern, are expected to also contribute to economic development (Grieg-Gran et al., 2005).

The analyzed schemes are based on the local perception that water provision is one of the main forest benefits, and the popular belief that larger upstream forest cover leads to both better downstream water quality and greater quantity (see Table 5). This perception seems to be common among rural dwellers in Latin America (Johson and Baltodano, 2004) and other tropical regions of the world (Wilk, 2000). Nevertheless, the disparity between public and scientific perceptions of the hydrological functions of forests is well documented (Tognetti et al., 2004). The gap between conventional wisdom and scientific evidence is summarized in Table 6. The relationship between land uses and hydrological dynamics is probably the most critical technical challenge of water-related PES schemes.

The expansion of forest cover may have a net positive impact on downstream water availability if the competing land use (e.g. agriculture) is intensive in water consumption. However, in most cases the empirical evidence shows that enlarging forest cover leads to lower water availability downstream. For that reason, even though there is little knowledge about the effects of tropical forest cover on groundwater flow (Grip et al., 2005), PES schemes aiming to increase water availability by means of expanding forest cover should be avoided, at least as a precautionary strategy. The assumptions about the relationship between land use and water-related environmental services are decisive for evaluating the cost-effectiveness of these instruments, and for establishing the direction of the payment. Indeed, a scheme in South Africa applies an opposite logic to those here described since it levies a charge on commercial afforestation areas, in order to compensate for the capture of water by new trees (Katilla and Puustjärvi, 2004).

Regarding the relationship between forest cover and water quality, there is a smaller mismatch between public and science perceptions. The empirical scientific evidence on that subject may be summarized as follows (Ayward, 2005):

- erosion increases with forest disturbance

- deforestation likely results in larger sedimentation rates

- forest-pasture conversion generally increases nutrient and chemical outflows, as leaching rises.

These conclusions highly coincide with the public perception that forest cover and water quality are positively correlated (see Table 5). PES schemes are more likely to be effective when they tackle water quality problems, since there is less technical uncertainty and less divergence between public expectations and scientific evidence on the relationship between land use and water quality.

The emphasis on the adoption of better environmental practices among upstream farmers most likely makes the PES scheme in Jesus de Otoro comparatively more cost-effective in achieving its main environmental goal, namely, to improve water quality. By creating incentives for forest protection, and therefore averting agricultural production (or other land uses), the schemes in Heredia and San Pedro may also have an impact on water quality, but possibly at the expense of 
reducing downstream water availability. More research is needed to test the assumptions of the relationships between land use and the provision of environmental services on which PES schemes rely upon (Kaimowitz, 2005). This will be a hard task owing to the intrinsic complexity, context-specificity, and scale-dependent nature of the hydrological functions of different land uses (Gautam et al., 2004; Mungai et al., 2004; van Noordwijk et al., 2004; Pattanayak, 2004; Tomich et al., 2004; Costa, 2005; Scott et al., 2005). However, there are interesting examples of community-based hydrological and water quality assessments (Deutsch et al., 2005), which might be replicated for reducing the operational costs of evaluating the effects of PES schemes on the condition of water resources.

The hydrological evidence summarized above suggests that there might be trade-offs in relation to the ability of PES to achieve different kinds of environmental goals, such as improvements of water quality, water availability and biodiversity protection. Equally, PES schemes may also face a trade-off between meeting environmental goals in the most cost-effective way and contributing to poverty alleviation (Kerr, 2002). Indeed, in the cases we have analyzed, the effects on upstream income are in general low, and in Heredia the PES go to wealthy providers (Heredia), or they are made by users who are poor. These trade-offs shed some doubts on PES schemes as win-win and multipurpose instruments. Nonetheless, the information gathered supports the view that these types of markets may contribute to solving social conflicts. In fact, in Jesus de Otoro, the PES scheme worked out as a tool for lessening conflicts between downstream and upstream stakeholders. This case suggests that PES schemes may aid in creating institutional settings for easing downstream-upstream cooperation and promoting conflict resolution. Nonetheless, in other cases, PES schemes may seem to announce permanent land rights changes, and may therefore face resistance by some social actors.

We have also found that preliminary technical studies did not noticeably influence the design of the selected PES. Initial decisions and the functioning of PES schemes were to a large extent the result of a complex social process, involving interactions between different stakeholders, rather than the outcome of a technical assessment. Our results also suggest that the calculation of upstream opportunity cost of forest cover based on on-farm profits in general overestimates actual willingness to accept compensation among providers. Equally, calculations of downstream willingness to pay probably overestimate politically and socially feasible fees. In our cases, the users' final payments were significantly below the initially estimated willingness to pay. Our impression is that economic valuations were more lip service than a real input to the decision making process in the cases we have analyzed. The amounts of the payments were the result of a long and complex negotiation process, in which local institutions and leadership played significant roles. When market transactions between downstream and upstream stakeholders are feasible, to give attention to social relations, perceptions, bargaining power, property rights and institutional aspects are probably more useful inputs to PES design than mere economic valuations. The social embeddedness of markets for environmental services and the social transformations they trigger are very relevant topics for future research.

\section{Acknowledgements}

This research was financed by the BBVA Foundation. We would like to thank all of the communities for their help and support during our fieldwork. We are also grateful for the comments and criticisms of an anonymous reviewer.

\section{R E F E R E N C E S}

Ayward, B., 2005. Land use, hydrological function and economic valuation. In: Bonell, M., Bruijnzeel, L. (Eds.), Forests, Water and People in the Humid Tropics. Cambridge University Press/ UNESCO.

Bergsma, E., 2000. Incentives of land users in projects of soil and water conservation, the weight of intangibles. GeoJournal 50, 47-54.

Bruijnzeel, L.A., Bonell, M., Gilmour, D., Lamb, D., 2005. Forests, water and people in the humid tropics: an emerging view. In: Bonell, M., Bruijnzeel, L. (Eds.), Forests, Water and People in the Humid Tropics. Cambridge University Press/UNESCO.

Calder, I.R., 2004. Forests and water: closing the gap between public and science perceptions. Water Science and Technology 49 (7), 39-53.

Coase, D., 1960. The problem of social cost. Journal of Law and Economics 3, 1-44.

Costa, 2005. Large-scale hydrological impacts of tropical forest conversion. In: Bonell, M., Bruijnzeel, L. (Eds.), Forests, Water and People in the Humid Tropics. Cambridge University Press/ UNESCO.

Deutsch, W., Busby, Orprecio, J., Bago-Labis, Cequiña, E., 2005. Community-based hydrological and water quality assessments in Mindanao, Philippines. In: Bonell, M., Bruijnzeel, L. (Eds.), Forests, Water and People in the Humid Tropics. Cambridge University Press/UNESCO.

Ferraro, P., Kiss, A., 2002. Direct payments to conserve biodiversity. Science 298, 1718-1719.

Gautam, A., Shivakoti, G., Webb, E., 2004. Forest cover change, physiography, local economy, and institutions in a mountain watershed in Nepal. Environmental Management 33 (1), 48-61.

Gibson, C., McKean, Ostrom, E. (Eds.), 2000. Communities, Institutions and Governance. MIT press, USA.

Grieg-Gran, M., Porras, I., Wunder, S., 2005. How can market mechanisms for forest environmental services help the poor? Preliminary lessons from Latin America. World Development 33 (2), 237-253.

Grip, H., Fritsch, J.-M., Bruijnzeel, L., 2005. Soil and water impacts during forest conversion and stabilization to new land use. In: Bonell, M., Bruijnzeel, L. (Eds.), Forests, Water and People in the Humid Tropics. Cambridge University Press/UNESCO.

Johson, N., Baltodano, M.E., 2004. The economics of community watershed management: some evidence from Nicaragua. Ecological Economics 49, 57-71.

Kaimowitz, D., 2005. Useful myths and intractable truths: the politics of the link between forests and water in Central America. In: Bonell, M., Bruijnzeel, L. (Eds.), Forests, Water and People in the Humid Tropics. Cambridge University Press/UNESCO.

Katilla, M., Puustjärvi, E., 2004. Markets for forest environmental services: reality and potential. Unasylva 219 (55), 53-58.

Kerr, J., 2002. Watershed development, environmental services, and poverty alleviation in India. World Development 30 (8), 1387-1400.

Landell-Mills, N., 2002. Developing markets for forest environmental services: an opportunity for promoting equity while securing efficiency? Philosophical Transactions of the Royal Society $360,1817-1825$. 
Landell-Mills, N., Porras, I., 2002. Silver bullet or fools' gold? A global review of markets for forest environmental services and their impact on the poor. IIED, London.

Lubell, M., Schneider, M., Scholz, J., Mete, M., 2002. Watershed partnership and the emergence of collective action institutions. American Journal of Political Science 46 (1), 148-163.

Mayrand, K., Paquin, M., 2004. Payments for Environmental Services: A Survey and Assessment of Current Schemes. Report elaborated by UNISFERA for the Commission for Environmental Cooperation of North America.

Miranda, M., Porras, I., Moreno, M.L., 2003. The social impacts of payments for environmental services in Costa Rica: a quantitative field survey and analysis of the Virilla watershed. International Institute for Environment and Development. IIED, London.

Mungai, D., Ong, C., Kiteme, B., Elkaduwa, W., Sakthivadivel, R., 2004. Lessons from two long-term hydrological studies in Kenya and Sri Lanka. Agriculture, Ecosystems \& Environment 104, 135-143.

Nathan, D., Kelkar, G., 2001. Case for local forest management, environmental services, internationalization of costs and markets. Economic and Political Weekly 2835-2845.

Ostrom, E., Dietz, T., Dolsak, N., Stern, P., Stovich, S., Weber, E. (Eds.), 2002. The Drama of the Commons. National Academy Press, Washington.

Pagiola, S., 2005. Can payments for environmental services help reduce poverty? An exploration of the issues and the evidence to date from Latin America. World Development 33 (2), 237-253.

Pagiola, S., Landell-Mills, N., Bishop, J., 2002a. Market-based mechanisms for forest conservation and development. In: Pagiola, S., Landell-Mills, N., Bishop, J. (Eds.), Selling Forest Environmental Services. Earthscan, London.

Pagiola, S., Landell-Mills, N., Bishop, J., 2002b. Making marketbased mechanisms work for forests and people. In: Pagiola, S., Landell-Mills, N., Bishop, J. (Eds.), Selling Forest Environmental Services. Earthscan, London.

Pagiola, S., Agostini, P., Gobbi, J., de Haan, C., Ibrahim, M., Murgueitio, E., Ramirez, E., Rosales, M., Ruiz, J.P., 2004. Paying for biodiversity conservation services in agricultural landscape. Environment Department Papers, vol. 96. World Bank.
Pattanayak, S., 2004. Valuing watershed services: concepts and empirics from Southeast Asia. Agriculture, Ecosystems \& Environment 104, 171-184.

Rosa, H., Kandel, S., Dimas, L., 2004. Compensation for environmental services and rural communities: lessons from the Americas. International Forestry Review 6 (2), 187-194.

Scott, D., Bruijnzeel, L., Mackensen, J., 2005. The hydrological and soil impacts of forestation in the tropics. In: Bonell, M., Bruijnzeel, L. (Eds.), Forests, Water and People in the Humid Tropics. Cambridge University Press/UNESCO.

Seabright, P., 1993. Managing local commons: theoretical issues in incentive design. Journal of Economic Perspectives 7 (4), 113-134

Taylor, M., Singleton, S., 1993. The communal resource: transaction costs and the solution of collective actions problems. Politics \& Society 21 (2), 195-214.

Tognetti, S., Mendoza, G., Ayward, B., Southgate, D., Garcia, L., 2004. A knowledge and assessment guide to support the development of payments arrangements for watershed ecosystem services. Report prepared for the World Bank Environment Department.

Tognetti, S., Ayward, B., Mendoza, G., 2005. Markets for watershed services. In: Anderson, M. (Ed.), Encyclopedia of Hydrological Sciences. John Wiley and Sons, UK.

Tomich, T., Thomas, D., van Noordwijk, M., 2004. Environmental services and land use change in Southeast Asia: from recognition to regulation or reward? Agriculture, Ecosystems \& Environment 104, 229-244.

van Noordwijk, M., Poulsen, J., Ericksen, P., 2004. Quantifying offsite effects of land use change: filters, flows and fallacies. Agriculture, Ecosystems \& Environment 104, 19-34.

Warner, K., Huang, M., Middleton, D., 2004. Financial Incentives to Communities for Stewardship of Environmental Resources: feasibility Study. Report prepared by Winrock for USAID.

Wilk, J., 2000. Local perceptions about forests and water in two tropical catchments. GeoJournal 50, 339-347.

Zbinden, S., Lee, D., 2005. Paying for environmental services: an analysis of participation in Costa Rica's PSA program. World Development 33 (2), 255-272. 